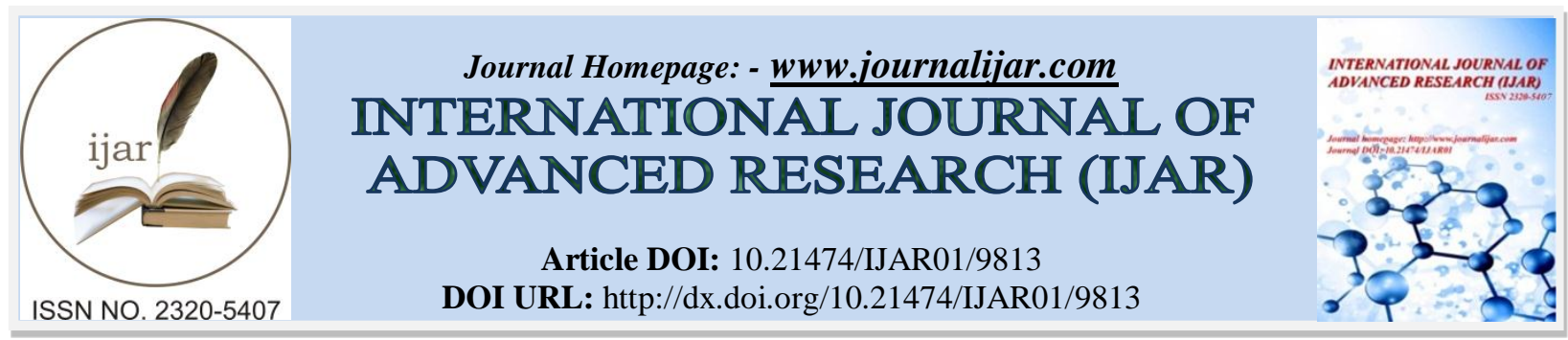

RESEARCH ARTICLE

\title{
OPTIMUM CROPPING PATTERN FOR FARMERS OF BIDAR DISTRICT, KARNATAKA.
}

1. Dileep Kumar Kanna, Civil Engineering Department, BKIT, Bhalki.585328 Bidar District, Karnataka, India.

2. Civil Engineering Department, P.D.A.College of Engineering, Kalburgi. 585101 Karnataka, India.

\section{Manuscript Info}

n.........................

Manuscript History

Received: 04 August 2019

Final Accepted: 06 September 2019

Published: October 2019

Key words:-

restricted capital, cropping pattern, reorganization of resources, impact of credit, Linear Programming Model, net farmers returns.

\begin{abstract}
In the present study optimal solutions were found for net farm returns using Linear Programming model on the sample farmers of Bidar District.The LINGO 17.0 package was used to get the solutions. The sample was of 120 small and large farmers collected from 15 villages from five Tehsils. From each village eight farmers comprising of small and large farmers were selected. A total of EIGHT models were developed. They were classified as small farmers S1, S2, S3, S4 and large farmers L1, L2, L3, and L4. The results were compared with existing cropping pattern of small and large farmers. The model S1, small farmers with existing technology and restricted capital registered an increase of net returns per hectare by $27 \%$, S2 small farmer with existing technology and relaxed capital returns increased by $34 \%$, S3 small farmer with recommended technology and restricted capital, returns increased by $55 \%, \mathrm{~S} 4$ small farmer with recommended technology and relaxed capital, the returns increased by $65 \%$ per hectare. Similarly the net returns per hectare in case of large farmers L1, L2, L3, L4 increased by 47\%, 65\%, 49\%, 76\% respectively. The impact of credit on net farm returns in small farmers was Rs: 8322 and the same in large farmers was Rs: 615276. It was noted that credit played an important role in augmenting income of farmers; the credit required was directly related to farm size while credit on income, inversely related to farm size.
\end{abstract}

Copy Right, IJAR, 2019,. All rights reserved.

\section{Introduction:-}

Agriculture plays an important role in shaping economy of our country. Its contribution to Gross Domestic Products (GDP) back in 1970 was about $44 \%$ has now reduced to $15 \%$ in 2018 , thanks to other sectors such as services. Nevertheless, the importance of agriculture is not likely wane away due to concerns of food security, employment, rural poverty and availability of wages as goods (Vijay, 2012). The population in India is growing at a rate of $1.4 \%$ will soon surpass the population of China (in 2027). The country needs to produce approximately 320 million tonnes of food grains, 290 million tonnes of vegetables and fruits, 185 million tonnes of milk, 26 million tonnes of meat, eggs and fish and 23 million tonnes of edible oil by 2022. (Joshi and Kumar 2001). The increasing demand of agricultural products coupled with limited availability of farm resources needs a careful exploration of production

Corresponding Author:-Dileep Kumar Kanna.

Address:-Dileep Kumar Kanna, Civil Engineering Department, BKIT, Bhalki.585328 Bidar

District. Karnataka India. 
pattern, exploring possibilities of increasing efficiency of resources on various sizes of farms (Paroda and Praduman, 2000). The efficiency in agriculture is achieved by optimum utilization of resources.

Agriculture in India, due to increased farm input cost and dwindling profitability of farm products have made it a losing proposition. In view of this, it has become imperative that the available resources should be used judiciously and economically since more is efficiency higher will be the income. In present study, an attempt has been made to analyze possibilities and prospects of increasing net farm income by rational allocation of resources through optimum production pattern, the objective of which is to ascertain existing resource pattern, develop optimum combination of resources for different models and compare with existing pattern.

\section{Materials and Methods:-}

The study was undertaken in Bidar District, Karnataka, which is an economically backward district. A total of 120 farmers were selected from five Tehsils, choosing three villages from each Tehsil. From these villages, four small farmers and four large farmers who have 2 hectares of land and more than 2 hectares of land respectively were selected. The study was conducted in the year 2018.

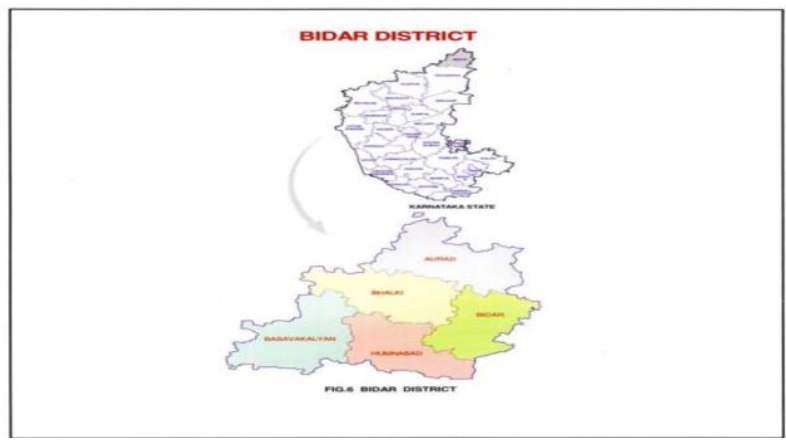

Fig 1:-Bidar Map

A linear programming model was used to explore the possibilities of optimizing net farm returns considering various crop activities.

Maximize $\mathrm{Z}=\sum_{\mathrm{i}=1}^{\mathrm{n}} \mathrm{CjXj} \quad$ where $\mathrm{j}=1$ to $\mathrm{n}$ activities

Subjected to:

$\sum_{\mathrm{j}=1}^{\mathrm{n}}$ aijXj $>=$ bi $\quad(\mathrm{i}=1$

$\sum_{\mathrm{j}=1}^{\mathrm{n}} \mathrm{aijXj} \quad<=b_{\mathrm{i}}$

$(\mathrm{i}=\mathrm{k}+1, \ldots \ldots \ldots \ldots \ldots \mathrm{m})$

$\sum_{\mathrm{j}=1}^{\mathrm{n}} \mathrm{aijXj}=\mathrm{b}_{\mathrm{i}}$

(i $=\mathrm{m}+1$,

$\mathrm{X}_{\mathrm{j}}, \mathrm{b}_{\mathrm{i}}>=0$ (Non negatives constraints)

where, $\mathrm{Z}=$ Objective Function,

$\mathrm{C}_{\mathrm{j}}=$ price of $\mathrm{j}^{\text {th }}$ activity during kharif and rabi season,

$\mathrm{X}_{\mathrm{j}}=$ unit of $\mathrm{j}^{\mathrm{th}}$ production activity during kharif and rabi,

$a_{i j}=$ amount of $i^{\text {th }}$ resource required by $j^{\text {th }}$ activity,

$b_{i}=$ quantity of $i^{\text {th }}$ resource.

With above model four optimum plans (Models) were developed for farm situation and compared for income and employment.

1. Model-1: Restricted Capital and Existing Technology

2. Model -2: Unrestricted or Relaxed capital and Existing Technology

3. Model-3: Recommended technology with restricted capital

4. Model-4: Recommended Technology with unrestricted capital.

The resources available for farm production were considered as constraints which are taken as: a) Land: Irrigated and Dry Land (e.g. kharif irrigated, kharif dry land, rabi irrigated and rabi and rabi dry land) b) Human Labour: level of human labour for family and hired c) bullock labour: available labour during peak period d) Tractor power: some farmers are hiring tractor power and hence included in the model. e) Capital: it is the expenditure incurred on seeds, fertilizers, and farm yard manure (FYM), pesticides, irrigation and other inputs taken as cash restriction during the 
plan period. The existing levels of all resources used on the farms were taken as maximum supply available on the farms. The constraints were set on FYM, N (Nitrogen), P (Phosphorous) and K (Potassium) for kharif and rabi. All crops grown on the farm were taken as real activity for present analysis.

The objective of the model was to maximize net annual returns on farm subject to resource constraints specified earlier. The net returns are obtained by deducting variable expenses from income. The variable costs were: the cost of seeds, manures, fertilizers, water, hired human labour and machine labour, pesticides, insecticides etc. The harvest prices were taken as output prices and the actual market prices of input at the time of application were taken as input prices.

\section{Results and Discussions:-}

The discussion of results from investigation carried out is made through analyzing and comparing the existing cropping pattern with optimal cropping and also comparing net farm returns on different farm sizes.

Table 1:-Cropping pattern for small farmers under different optimal plans

\begin{tabular}{|c|c|c|c|c|c|c|c|c|c|c|c|}
\hline \multirow{2}{*}{$\begin{array}{l}\mathrm{S} 1 \\
\mathrm{~N} \\
\mathrm{o}\end{array}$} & \multirow{2}{*}{$\begin{array}{l}\text { Particular } \\
\text { s of Crop }\end{array}$} & \multicolumn{2}{|c|}{ Existing } & \multicolumn{2}{|c|}{ S1 } & \multicolumn{2}{|c|}{ S2 } & \multicolumn{2}{|c|}{ S3 } & \multicolumn{2}{|c|}{ S4 } \\
\hline & & $\begin{array}{c}\text { Area } \\
\text { (ha) }\end{array}$ & $\begin{array}{c}\text { Percen } \\
\mathrm{t}\end{array}$ & $\begin{array}{l}\text { Area } \\
\text { (ha) }\end{array}$ & $\begin{array}{c}\text { Percen } \\
\mathrm{t}\end{array}$ & $\begin{array}{l}\text { Area } \\
\text { (ha) }\end{array}$ & $\begin{array}{c}\text { Percen } \\
\mathrm{t}\end{array}$ & $\begin{array}{l}\text { Area } \\
\text { (ha) }\end{array}$ & $\begin{array}{c}\text { Percen } \\
\mathrm{t}\end{array}$ & $\begin{array}{c}\text { Area } \\
\text { (ha) }\end{array}$ & $\begin{array}{c}\text { Percen } \\
t\end{array}$ \\
\hline 1 & \multicolumn{11}{|c|}{ Kharif Dry Land } \\
\hline $\mathrm{a}$ & Soya bean & 0.36 & 33.33 & 0.00 & 0.00 & 0.00 & 0.00 & 0.20 & 18.52 & 0.63 & 58.30 \\
\hline $\mathrm{b}$ & $\begin{array}{l}\text { Black } \\
\text { gram }\end{array}$ & 0.28 & 25.92 & 0.00 & 0.00 & 0.00 & 0.00 & 0.78 & 72.22 & 0.20 & 18.52 \\
\hline $\bar{c}$ & $\begin{array}{l}\text { Green } \\
\text { gram }\end{array}$ & 0.21 & 19.44 & 0.00 & 0.00 & 0.00 & 0.00 & 0.00 & 0.00 & 0.10 & 9.30 \\
\hline $\mathrm{d}$ & Red gram & 0.24 & 22.22 & 1.08 & 100 & 1.08 & 100 & 0.10 & 0.09 & 0.15 & 13.88 \\
\hline & Fallow & -- & -- & -- & -- & --- & -- & ---- & --- & --- & --- \\
\hline & Total & 1.08 & 100 & 1.08 & 100 & 1.08 & 100 & 1.08 & 100 & 1.08 & 100 \\
\hline 2 & \multicolumn{11}{|c|}{ Kharif Irrigated Land } \\
\hline $\mathrm{a}$ & Sugarcane & 0.33 & 64.70 & 0.18 & 36.07 & 0.41 & 80.40 & 0.00 & 0.00 & 0.00 & 0.00 \\
\hline $\mathrm{b}$ & $\begin{array}{l}\text { Bengal } \\
\text { gram }\end{array}$ & 0.18 & 35.30 & 0.10 & 19.61 & 0.10 & 19.60 & 0.10 & 19.60 & 0.51 & 100 \\
\hline & Fallow & -- & -- & 0.23 & 44.31 & -- & -- & 0.41 & 80.40 & 0.00 & 0.00 \\
\hline & Total & 0.51 & 100 & 0.51 & 100 & 0.51 & 100 & 0.51 & 100 & 0.51 & 100 \\
\hline \multirow[t]{3}{*}{3} & \multicolumn{11}{|c|}{ Rabi Dry Land } \\
\hline & Fallow & 1.08 & 100 & 1.08 & 100 & 1.08 & 100 & 1.08 & 100 & 1.08 & 100 \\
\hline & Total & 1.08 & 100 & 1.08 & 100 & 1.08 & 100 & 1.08 & 100 & 1.08 & 100 \\
\hline 4 & \multicolumn{11}{|c|}{ Rabi Irrigated Land } \\
\hline $\mathrm{a}$ & Sugarcane & 0.33 & 64.70 & 0.18 & 35.29 & 0.41 & 80.40 & 0.00 & 0.00 & 0.00 & 0.00 \\
\hline $\mathrm{b}$ & Onion & 0.18 & 35.30 & 0.33 & 64.71 & 0.10 & 19.60 & 0.51 & 100 & 0.51 & 100 \\
\hline & Total & 0.51 & 100 & 0.51 & 100 & 0.51 & 100 & 0.51 & -- & 0.51 & --- \\
\hline 5 & $\begin{array}{l}\text { Cropping } \\
\text { Intensity } \\
(\%)\end{array}$ & 132 & ---- & 118 & ---- & 132 & ---- & 106 & -- & 132 & -- \\
\hline 6 & $\begin{array}{l}\text { Net farm } \\
\text { returns for } \\
\text { total } \\
\text { cultivated } \\
\text { area (Rs:) }\end{array}$ & $\begin{array}{c}7452 \\
0\end{array}$ & ---- & $\begin{array}{c}10519 \\
6\end{array}$ & ---- & $\begin{array}{c}11351 \\
8\end{array}$ & ---- & 165332 & -- & $\begin{array}{c}21222 \\
9\end{array}$ & -- \\
\hline 7 & $\begin{array}{l}\text { Net farm } \\
\text { returns } \\
\text { per } \\
\text { Hectare } \\
\text { cultivated } \\
\text { area (Rs:) }\end{array}$ & $\begin{array}{c}4693 \\
1\end{array}$ & ---- & 66161 & ---- & 71395 & ---- & $\begin{array}{c}10398 \\
2\end{array}$ & -- & $\begin{array}{c}13347 \\
7\end{array}$ & -- \\
\hline
\end{tabular}


Table 2:-Impact of Credit on Employment of Small and Large Farmers:

\begin{tabular}{|c|c|c|c|c|}
\hline \multirow{2}{*}{ Category } & \multicolumn{2}{|c|}{ Existing Technology } & \multicolumn{2}{c|}{ Change Over } \\
\cline { 2 - 5 } & Model 1 & Model 2 & Absolute & Percent \\
\hline \multicolumn{4}{|c|}{ Small Farmers } \\
\hline Mandays & 24.34 & 36.07 & 11.73 & 48.19 \\
\hline Womendays & 42.16 & 57.96 & 15.84 & 37.47 \\
\hline Bullock days & 6.26 & 8.97 & 2.71 & 23.29 \\
\hline Tractor Hours & 1.93 & 1.48 & -0.45 \\
\hline \multicolumn{5}{|c|}{ Large Farmers } \\
\hline Mandays & 76.97 & 249.9 & 172.93 & 224.67 \\
\hline Womendays & 149.11 & 387.40 & 283.29 & 189.98 \\
\hline Bullock days & 19.49 & 55.16 & 35.67 & 183.01 \\
\hline Tractor Hours & 14.92 & 53.13 & 38.21 & 256.09 \\
\hline
\end{tabular}

Table 3:-Cropping Pattern for large farmers under different optimal plans

\begin{tabular}{|c|c|c|c|c|c|c|c|c|c|c|c|}
\hline \multirow{2}{*}{$\begin{array}{l}\text { Sl } \\
\text { N } \\
\mathrm{o}\end{array}$} & \multirow{2}{*}{$\begin{array}{l}\text { Particulars } \\
\text { of Crop }\end{array}$} & \multicolumn{2}{|c|}{ Existing } & \multicolumn{2}{|l|}{ L1 } & \multicolumn{2}{|l|}{ L2 } & \multicolumn{2}{|l|}{ L3 } & \multicolumn{2}{|l|}{ L4 } \\
\hline & & $\begin{array}{l}\text { Area } \\
\text { (ha) }\end{array}$ & $\begin{array}{l}\text { Percen } \\
\mathrm{t}\end{array}$ & $\begin{array}{l}\text { Area } \\
\text { (ha) }\end{array}$ & $\begin{array}{l}\text { Percen } \\
\mathrm{t}\end{array}$ & $\begin{array}{l}\text { Area } \\
\text { (ha) }\end{array}$ & Percent & $\begin{array}{l}\text { Area } \\
\text { (ha) }\end{array}$ & Percent & $\begin{array}{l}\text { Area } \\
\text { (ha) }\end{array}$ & $\begin{array}{l}\text { Percen } \\
\mathrm{t}\end{array}$ \\
\hline 1 & \multicolumn{11}{|c|}{ Kharif Dry Land } \\
\hline $\mathrm{a}$ & Soya bean & 1.76 & 39.82 & 0.50 & 11.31 & 0.50 & 11.31 & 0.50 & 11.31 & 0.80 & 18.10 \\
\hline $\mathrm{b}$ & Black gram & 0.90 & 20.36 & 0.40 & 9.00 & 0.40 & 9.00 & 2.40 & 5.30 & 3.42 & 77.37 \\
\hline $\mathrm{c}$ & Green gram & 0.98 & 22.17 & 0.00 & 0.00 & 0.00 & 0.00 & 0.10 & 2.26 & 0.20 & 4.57 \\
\hline \multirow[t]{3}{*}{$\mathrm{d}$} & Red gram & 0.79 & 17.29 & 0.15 & 3.40 & 3.52 & 79.63 & 0.00 & 0.00 & 0.00 & 0.00 \\
\hline & Fallow & -- & -- & 3.37 & 76.24 & -- & -- & --- & --- & --- & -- \\
\hline & Total & 4.42 & 100 & 4.42 & 100 & 4.42 & 100 & 4.42 & 100 & 4.42 & 100 \\
\hline 2 & \multicolumn{11}{|c|}{ Kharif Irrigated Land } \\
\hline $\mathrm{a}$ & Sugarcane & 0.50 & 30.54 & 0.10 & 0.05 & 0.10 & 0.00 & 1.00 & 6.00 & 0.10 & 6.00 \\
\hline \multirow[t]{7}{*}{$\mathrm{b}$} & Ginger & 0.53 & 31.73 & 0.01 & 0.05 & 0.01 & 0.10 & 0.00 & 0.00 & 0.00 & 0.00 \\
\hline & Paddy & 0.36 & 21.55 & 1.08 & 64.67 & 0.16 & 99.90 & 0.00 & 0.00 & 0.00 & 0.00 \\
\hline & Onion & 0.14 & 8.34 & 0.00 & 0.00 & 0.00 & 0.00 & 0.00 & 0.00 & 0.00 & 0.00 \\
\hline & Tomato & 0.18 & 10.78 & 0.00 & 0.00 & 0.00 & 0.00 & 0.00 & 0.00 & 0.10 & 6.00 \\
\hline & Chilies & 0.18 & 10.78 & 0.00 & 0.00 & 0.00 & 0.00 & 0.38 & 22.75 & 1.47 & 88.00 \\
\hline & Fallow & -- & -- & 0.48 & 28.74 & -- & 0.00 & 1.19 & 71.25 & -- & --- \\
\hline & Total & 1.67 & 100 & 1.67 & 100 & 1.67 & 100 & 1.67 & 100 & 1.67 & 100 \\
\hline 3 & \multicolumn{11}{|c|}{ Rabi Dry Land } \\
\hline & $\begin{array}{l}\text { Bengal } \\
\text { gram }\end{array}$ & 2.21 & 50.00 & 0.00 & 0.00 & 0.00 & 0.00 & 1.00 & 6.00 & 0.10 & 6.00 \\
\hline & Jowar & 0.55 & 12.44 & 2.92 & 66.06 & 0.00 & 0.00 & 0.00 & 0.00 & 0.00 & 0.00 \\
\hline & Safflower & 0.44 & 9.95 & 0.00 & 0.00 & 4.42 & 100 & 0.00 & 0.00 & 0.00 & 0.00 \\
\hline & Fallow & 1.21 & 27.37 & 1.50 & 33.93 & 0.00 & 0.00 & 0.00 & 0.00 & 0.00 & 0.00 \\
\hline & Total & 4.42 & 100 & 4.42 & 100 & 4.42 & 100 & 0.00 & 0.00 & 0.10 & 6.00 \\
\hline 4 & \multicolumn{11}{|c|}{ Rabi Irrigated Land } \\
\hline $\mathrm{a}$ & Sugarcane & 0.50 & 30.54 & 0.00 & 0.00 & 0.00 & 0.00 & 0.10 & 6.00 & 0.10 & 6.00 \\
\hline \multirow[t]{5}{*}{$\mathrm{b}$} & Ginger & 0.30 & 17.96 & 0.00 & 0.00 & 0.00 & 0.00 & 0.00 & 0.00 & 0.00 & 0.00 \\
\hline & Chilies & 0.18 & 10.78 & 0.00 & 0.00 & 0.00 & 0.00 & 0.38 & $\begin{array}{c}22.7 \\
5\end{array}$ & 1.47 & 88.00 \\
\hline & Wheat & 0.34 & 20.36 & 0.16 & $\begin{array}{l}93.4 \\
0\end{array}$ & 1.56 & $\begin{array}{l}93.4 \\
1\end{array}$ & 0.00 & 0.00 & 0.10 & 6.00 \\
\hline & Fallow & 0.34 & 20.36 & 0.11 & 6.60 & 0.11 & 6.60 & 1.19 & $\begin{array}{c}71.2 \\
6\end{array}$ & 0.00 & 0.00 \\
\hline & Total & 1.67 & 100 & 0.67 & 100 & 1.67 & 100 & 1.67 & 100 & 1.67 & 100 \\
\hline 5 & $\begin{array}{l}\text { Cropping } \\
\text { Intensity }\end{array}$ & 174 & ---- & 110 & --- & 198 & & 161 & -- & 200 & -- \\
\hline
\end{tabular}




\begin{tabular}{|c|c|c|c|c|c|c|c|c|c|c|}
\hline & $(\%)$ & & & & & & & & & \\
\hline 6 & $\begin{array}{l}\text { Net farm } \\
\text { returns } \\
\text { for total } \\
\text { cultivate } \\
\text { d area } \\
\text { (Rs:) }\end{array}$ & $\begin{array}{l}61207 \\
6\end{array}$ & ---- & $\begin{array}{l}115648 \\
1\end{array}$ & ---- & 1771757 & $\begin{array}{c}120387 \\
2\end{array}$ & -- & $\begin{array}{c}255205 \\
1\end{array}$ & -- \\
\hline 7 & $\begin{array}{l}\text { Net farm } \\
\text { returns } \\
\text { per } \\
\text { Hectare } \\
\text { cultivate } \\
\text { d area } \\
\text { (Rs:) }\end{array}$ & $\begin{array}{l}10049 \\
7\end{array}$ & ---- & 189898 & ---- & 290929 & 197680 & -- & 419056 & -- \\
\hline
\end{tabular}

Table 4:-Net Returns small and large farmers under different optimal models (Rs:)

\begin{tabular}{|l|l|l|l|l|l|l|l|c|c|}
\hline Category & Existing & $\begin{array}{l}\text { Model - } \\
1\end{array}$ & $\begin{array}{l}\text { Change } \\
\text { Over E- } \\
\text { Plan }\end{array}$ & $\begin{array}{l}\text { Model - } \\
2\end{array}$ & $\begin{array}{l}\text { Change } \\
\text { Over E- } \\
\text { Plan }\end{array}$ & Model - 3 & $\begin{array}{l}\text { Change } \\
\text { Over E- } \\
\text { Plan }\end{array}$ & $\begin{array}{l}\text { Model - } \\
4\end{array}$ & $\begin{array}{l}\text { Change } \\
\text { Over E- } \\
\text { Plan }\end{array}$ \\
\hline $\begin{array}{l}\text { Small } \\
\text { Farmers }\end{array}$ & 74620 & 105196 & 30576 & 113518 & 38898 & 165332 & 90712 & 212229 & 137609 \\
\hline $\begin{array}{l}\text { Large } \\
\text { Farmers }\end{array}$ & 612076 & 1156480 & 544405 & 1771757 & 1159681 & 1203872 & 591796 & 2552051 & 1939975 \\
\hline
\end{tabular}

Table 5:-Impact of Credit on Net Farm Returns of Small and Large Farm in (Rs:)

\begin{tabular}{|c|c|c|c|c|c|c|}
\hline \multirow{2}{*}{ Category } & \multicolumn{3}{|c|}{ Existing Technology } & \multicolumn{3}{c|}{ Recommended Technology } \\
\cline { 2 - 6 } & Model 1 & Model 2 & $\begin{array}{c}\text { Change Over } \\
\text { Model 1 }\end{array}$ & Model 3 & Model 4 & Change Over Model 3 \\
\hline $\begin{array}{c}\text { Small } \\
\text { Farmers }\end{array}$ & 105196 & 113518 & 8322 & 165332 & 212229 & 46897 \\
\hline $\begin{array}{c}\text { Large } \\
\text { Farmers }\end{array}$ & 1156481 & 1771757 & 615276 & 1203872 & 2552051 & 1348179 \\
\hline
\end{tabular}

In optimal solution of small farmers S1, only one crop red gram emerged as $100 \%$ cropped area in kharif dry land while in kharif irrigated land sugarcane, Bengal gram found their places. In rabi irrigated, onion (64.71\%) emerged as dominant crop followed by sugarcane (35.29\%). In S-2 model, under relaxed capital, the area of sugarcane increased to $80.40 \%$ due to availability of funds and Bengal gram again found its place due to local affinity. Interestingly there was no irrigated land left as fallow as was the case in model S1. The cropping intensity too increased to $132 \%$ from $118 \%$ compared to $\mathrm{S} 1$ and net farm returns also increased.

In model S3, under recommended technology with restricted capital black gram and soya bean emerged as optimal solutions in kharif dry land with $72 \%$ and $18 \%$ cropped area respectively while large amount of land 0.41 , hectares $(80 \%)$ was left fallow which may be due to restrictions imposed on capital and only $20 \%$ of area was occupied by Bengal gram in kharif irrigated land. The rabi dry land was again left fallow as was the case in existing cropping pattern. In rabi irrigated land only onion with $100 \%$ area found its place. Sugar cane which is an important cash crop in the region did not find its place. Due to this the cropping intensity reduced to $106 \%$ from $132 \%$ in existing pattern. The model however registered an increase in net return per hectare by $55 \%$. In model S4, Bengal gram, soya bean and onion emerged as dominant crops followed by black gram and red gram. The model did not allocate land to any crop in rabi dry land. In rabi irrigated land onion occupied $100 \%$ area becoming only crop in that season. The cropping intensity increased slightly to $132 \%$ relative to model S3. The net increasein returns per hectare was $65 \%$.

In optimal solutions of large farmers L1 from Table 2, large area of land (76.24\%) was left fallow, may be due to restriction on funds in kharif dry land. Only soya bean and black gram found places with areas as $11.31 \%$ and $9 \%$ respectively. In kharif irrigated land paddy was dominant with $64.67 \%$ area followed by fallow land with $28.74 \%$, sugarcane was little with only $0.05 \%$. In rabi dry land surprisingly jowar was dominant with $66.06 \%$ followed by 
again fallow land 33.93\%. In rabi irrigated land wheat with 93.4\% was dominant. In model L2 of large farmers with relaxed capital in kharif dry land red gram with $79.63 \%$ emerged as dominant crop followed by soya bean and black gram. In kharif irrigated land paddy emerged as dominant with $99.9 \%$ while in rabi dry land only one crop safflower found place and in rabi irrigated wheat with $93.41 \%$ and fallow land with $6.6 \%$ were formed as optimal solutions. The net cropping intensity was found to be $198 \%$ which is due to relaxed capital. Paddy and wheat which are food crops have emerged as dominant crops in both seasons.

In model L3, black gram (54.3\%) and soya bean (11.3\%) emerged as feasible crops in kharif dry land followed by green gram $2.26 \%$. Large amount of land $32 \%$ was left as fallow. This could be due to scarcity of funds faced by the farmer. In kharif irrigated land chilies with $22.75 \%$ and sugar cane with $6 \%$ found their places while $71 \%$ of land was again left fallow. This is not desirable as country like ours irrigated land cannot go uncultivated. In rabi dry land only one crop jowar found its place with $100 \%$ area. While in rabi irrigated land sugar cane and chilies continued their occupation and no new crop emerged. Again $71 \%$ of the land was left fallow. In model L4, black gram, soya bean emerged as optimal solutions in kahrif dry land followed by green gram while in kharif irrigated land the model has utilized entire irrigated area giving $88 \%$ to chilies and $6 \%$ each to sugar cane and tomato. In rabi dry land jowar occupied $97 \%$ while Bengal gram occupied only $3 \%$. In rabi irrigated land chilies continued its occupation from previous season and so was with sugar cane. Wheat found its place with $6 \%$ area in this model. The cropping intensity increased to $200 \%$ for the first time in all three models. Also the increase in returns were up, to $76 \%$.

The net increases in returns in small farmers in model 1 compared to existing is Rs:30576 (29\%) in Table 4 and in case of model 2 it is Rs:38898 (24\%) and the net increase in recommended technology was Rs:90712 (54.8\%) for S3 and for S4 the increase was Rs:137609 (64\%). Similarly in case large farmers in model 1 under restricted capital the increase in net returns compared to existing pattern was Rs:544405 (47\%) and in case of model 2 the increase was Rs:115968 (65\%).The increase in the return under recommended technology in model L3 was Rs:591796 (49\%). Similarly the net increase in model L4 was Rs: 1939975 (76\%). The impact of credit on net farm returns from Table 5 for small farmers is Rs: 8322 and for large farmers it is Rs: 61527. The employment generated by the model is not very encouraging. In case of small farmers in model S1 and S2 as family labour was sufficient and no hired labour was required. But in case of large farmers under relaxed capital the employment was generated in case of tractor hours and women labour. The Table 2 gives impact of credit on employment which is significant in case of large farmers where an increase of tractor hours and Man days of 256 and 224 percent respectively.

\section{Conclusion:-}

The study has brought out that there is a huge scope for increasing the net farm returns on both dry land and irrigated farm lands through reorganization of resources. The results also revealed that credit played an important role in increasing the income through reallocation of resources. Hence the farmers in the area be educated regarding the benefits of optimization techniques and they also be provided with short term credit facilities so that their net farm returns are increased. It was noted that credit required was directly related to farm size while credit on income, inversely related to farm size.

\section{References:-}

1. Aparnati,M., Bhatt,D. 2014. "Linear Programming Model for Optimal Cropping Pattern for Economic Benefits of Mrbc Command Area." IJIRST international Journal for Innovative Research in Science \& Technology. Pp 47-54.

2. Firzone,J.A.,Coelho,R.D.,Dourado-Neto,D.,Solani.R.,1997. "Linear Programming Model to optimize the water Resource Use in Irrigation Projects; An Application to the Senator Nilo Coelho Project." Science Agriculture, Piracicaba 1997. Pp 136-148.

3. Paroda R.S. and Praduman kumar 2000. "Food Production and Demand in South Asia." Agricultural Economics Research Review. 13(1): 1-24

4. Joshi, P.K. and Kumar, P. 2011. Food demand and supply projections for India,Mimeo. International Food Policy Research Institute (Asia Office), New Delhi.

5. Vijay Paul Sharma. 2012. "India's agricultural development under the new economic regime policy perspective and strategy for the 12th Five year plan." Indian Journal of Agricultural Economics. 67(1): 46-78.Science \& Technology. Pp 47-54.

6. Birhanu,T.K., Almirew, T., 2015. Optimizing Cropping Pattern Using Chance Constraint Linear Programming For Koga Irrigation Dam, Ethiopia. Irr.\& Drain. Systems Engg. Vol 4 Issue 2 p 35-46 
7. Dahiphale.P., Singh, P.K. 2015. Optimal Cropping Pattern for Jaisamnd Command of Udaipur District in Rajasthan, India. Research Journal of Recent Sciences. P 1-7.

8. Firzone,J.A.,Coelho,R.D.,Dourado-Neto,D.,Solani.R.,1997. Linear Programming Model to optimize the water Resource Use in Irrigation Projects; An Application to the Senator Nilo Coelho Project. Science Agriculture, Piracicaba 1997. Pp 136-148.

9. Gadge,S.B., Goruntwar S.B., 2014. "Linear Programming approach for Allocation of Land and Water Resources in Canal Command Area under Surface Method of Irrigation- A Case Study." Int. Jour. of Innovative Research in Science, E\&T. p 153-168.

10. Goswami, S.N. 2002. "Farm planning in hills of Meghalaya for augmentation of income and employment vis-àvis preservation of natural resource base." Indian Journal of Agricultural Economics. 57(2): 211 - 223.

11. Hassan Ishtiaq., A.R. Muhammad, Khalil,M, 2004. "Determination of optimum cropping pattern in Faislanbad Division (Pakistan)," International Journal of Agriculture \& Biology 06-5: 901-903.

12. Hassan I.,Shahbaz.M.T. 2008. "Impact of Increase in Wheat support Price on the Acreage and Income of the Farmers of Faislabad, "Division. Life Science International Journal p 543-546.

13. Jehanjeb., Malik Zilakat Khan, 2012. "Linear Programming Model and Sensitivity Analysis of Selected Agrarian Constraints Faced By Farming in The Provinces of Khaiber Pakhtunkhwa," City University Research Journal, Volume 3 No1 June 2012, Article 01: 20-24.

14. Jabeli.J., Patterson.B.2016." A Linear Programming Model to Optimize Cropping Pattern in Small - Scale Irrigation Schemes; An Application to Mekabo Scheme in Tigray, Ethiopia." International Journal of Environmental\& Agriculture Research (IJOEAR). P24-34. 